\title{
FOOTBALL AND ROMANIAN MASCULINITY. HOW IT IS CONSTRUCTED BY THE SPORT MEDIA?
}

\section{LÁSZLÓ PÉTER 1}

\begin{abstract}
The present article is focusing on hegemonic masculinity represented and expressed by the professional footballers. Based on the empirical study using text analysis of leading articles published in central Romanian sport newspapers I draw the ideal-typical picture of the normative model of Romanian hegemonic masculinity in which the domestic coaches play a determinant role. Their personal-individual and collective-professional features like determination, steadiness, honesty, pride, mutual respect, knowledge, tenaciousness, sense of vocation, solidarity, spirit of fighting are the corner points of the constructed Romanian manhood, or hegemonic masculinity during social change. The manliness is traced along the inner characteristic of the coaches but in strong contradiction with the foreign trainers. In this respect I can state that football is connected not only with masculinity but in some respect also with the national characteristics embodied by the Romanian coaches especially those working home.
\end{abstract}

Keywords: football, hegemonic masculinity, media, discourses

\section{Introduction}

Football and masculinity had been connected: ball games were played by men as early as in the antiquity and in the Middle Ages. It can be assumed that the "game", often leading to fights, hitting and affray, provided an opportunity to men to express and show their physical strength, resolution and masculine qualities to the women of the community. Playing ball games meant public/ community events, during which participant men could leave the monotonous routine of everyday life behind and could show off their masculine features to their audience. ${ }^{2}$ Team sports represent socializing frames in which competing or contesting men acquire and express the institutional and organized standards of their masculinity (Anderson, 2008). A range of research prove that sexually

\footnotetext{
1 Department of Sociology and Social Work in Hungarian, Babeș-Bolyai University Cluj-Napoca, email: peter.laszlo@socasis.ubbcluj.ro.

2 These masculine features changed during history, and are different by culture.
} 
segregated sports promote orthodox forms of masculinity, reproduce and cultivate sexist, anti-feminist attitudes against women (Anderson, 2008: 275). In this article I am going to present the connections between hegemonic masculinity and football as well as the normative forms or Romanian men based on text analysis of 3,287 written leading articles in specialised sport newspapers (ProSport, GSP and Digisport) for the 2008-2013 period. ${ }^{3}$

\section{Manly Football and the Football Man}

Hegemonic masculinity is the central and controversial concept in masculine studies, developed by Connell $(1983,1995,2002)$ after conducting a study on social inequality in high school (Connell et al., 1982 in Connell-Messerchmidt, 2005: 830). They found that class position and gender has a great influence on inequality. Certain forms of culturally constructed masculinity - an idealised male body along with the personal experiences and meanings regarding men's own bodies - allow men's dominance over women and over other forms of masculinities. Later, studies conducted on men life histories, including sportsmen (Connell, 1990), produced new accounts. This type of masculinity influences and determines gender relations in favour of dominant, usually white, heterosexual, urban, upper-middle class and educated men in society. Using the Gramscian notion of hegemony, hegemonic masculinity is a dynamic feature, which can change over time and context, due to cultural transformation. We are dealing with different types of masculinities: not just hegemonic and subordinated masculinity but also with immigrant worker masculinity and other alternative forms of nonhegemonic, alternative masculinities. There is a struggle and competition in making of the dominant masculine form (Connell-Messerchmidt, 2005: 831) specific for different social and cultural milieu. Nevertheless, the "here and now" valid form of hegemonic masculinity has a normative function, but is not the normal form of masculinity; it is 'embodied' only by a minority of men in society. The mediated football has an important role in the cultural construction and ideological legitimation of the ideal and normative model of hegemonic masculinity (Messner, 2004). In this respect, the media representation of sportsmen works

\footnotetext{
3 The research was supported by the Department of Art and Culture Studies, University of Jyväskylä. Parts are based on the thesis Péter, László (2014) Soccer and Society in Romania. Issues and Problems in Soccer Discourses, Jyväskylä: University of Jyväskylä (see pages 43-57 and 290-295). This period is very interesting, even unique: in these five years, the Romanian professional championship was dominated by teams outside from Bucharest. The winners came from the province: CFR 1907 (3 titles), Unirea Urziceni (1 title) and Oțelul Galați (1 title). This ignited the soccer discourses treating many social problems, too, ranged from masculinity to inter-ethnic relations, regional conflicts, labour rights.
} 
as instrument promoting what it means to be a man (Trujillo, 1991). Trujillo, in his study on baseball player Nolan Ryan states that there are five masculine features highlighted by the sport media on masculinity: physical force and control, occupational achievement, familial patriarchy, frontiermanship and heterosexuality (290-291). So, we see football as an instrument to shape, to create and to represent the socially required and desired/valued form of masculine traits and male bodies.

It is a fact that we almost obvious think that football is primarily a men's sport: mostly men play it and a considerable part of the spectators are men. In spite of the fact that the number of female spectators is continuously increasing, football has yet been connected with masculinity. ${ }^{4}$ Watching football matches, knowing the footballers' names by heart, recalling the names of old members of the team - all these are considered to be masculine activities. It seems that some type of enthusiasm towards football is a compulsory element to be followed by the masculinity established by society. The auditorium is a social space reserved especially for men, just as the adjacent activities. A popular female coach or authentic female commentators are still unimaginable: stadiums remain the space of masculine competition and of competitive masculinity, one of the scenes where modern man is born (Hadas, 2003). In this respect, the function of media ${ }^{5}$ is of utmost importance (Archetti, 1999).

The promotions of the transmitted derbies also indicate the close relationship between football and masculinity. For example, the match previews

\footnotetext{
4 My statement is valid where football is the most popular sports. I am aware that models of masculinity are not determined or mirrored back solely by football. In comparison with ice-hockey, classical masculinity transmitted by present-day football is more "feminine" than what we find in Canada, the USA or in Finland: players hardly have body hair, and the metrosexual model before the economic crisis was stronger than in the case of hockey players, where the majority have beards and the occurrence and intensity of legitimate violence - body check, toss and sometimes punching - is much higher. Presently, after the crisis this "warrior-like" image is specific to football, too. The scene of hockey is the locus of war likeness, of "elegant macho". I consider important the masculine models appearing alongside football because the model of masculinity becomes socially normative, it gives models. Masculinity is not only constituted in stadiums: players are presented on screens in numerous situations, thus the dresses, jewels, watches, poses, styles of speaking provide further elements to the model of present-day masculinity.

5 The sponsor of the Romanian Cup is the Timișoreana beer factory. The division by gender, and the division of labour according to gender of the performers appearing in the 40-second official promotion video is expressive in this respect. According to the moral of the video entitled Timisoreana Carries on the History of Romanian Soccer, the history of football practically is the story of men bringing the name of Romanian into repute. Women appear solely in secondary roles paying attention to male supporters and not to the match; in stadiums and bars only men are present. The female roles are limited to provide men with beer, and exclusively at home - this being an organic part of their housekeeping tasks. In segregated homosocial spaces, we can see exclusively men. These male supporters represent the real characters of football history developed in time - suggesting that football is a masculine business.
} 
transmitted by DigiSport channel are generally built on the aggressive appearance of the team leaders or players considered to be more violent, on their stout warwhoop, cruel "declaration of war" addressed to the opponent team, on their symbolic intimidating. In these short films with plenty of action, football players are presented as men capable of anything, going to war dressed in tribal colours, promising death to the members of the opponent team. The atmosphere, colours, background music of these videos quote the sombre world of ancient warriors, where men are physically and spiritually prepared to the final clash for the common good, the "stake" of which is to defend the members of the lineage tribal community, to finally destroy the opponent tribe and to protect the old, the children and the women. The portrayed males are physically strong, committed to their community, well organised, and stand by each other; they are ready for the greatest sacrifice at any time (it is often announced that "if it's necessary we are ready to die"). Men fulfil an instrumental role, their importance is strategic, and they are the sources of solidarity for the community, strengthen the collective consciousness. In other words, they are the symbolic (tribal) representatives of hegemonic masculinity.

\section{Football, Masculinity and Homosocial Male Spaces}

Social situation, self-image and legitimate roles of men are determined by social conditions. Options of masculinity have changed with the transformations of historical contexts, which changed both men's social situation and dominant meanings and characteristics of masculinity. Present masculine forms are in crisis according to Kimmel (Kimmel, 1996 in Nylund, 2007: 7) as a result of the uncertainty generated by the quick change of the economic structure of postindustrial societies. According to Nylund (2007) masculine options are limited; there has hardly remained a social space for the post-modern Western man to experience and express his masculinity without social limitations (8-9). So sports are one of a few legitimate arenas to express masculinity.

In urbanizing world, men had the opportunity to create homosocial social spaces (spaces created by people of the same gender), in the growing cities, where they could rediscover and practice their masculine characteristics: clubs frequented by men, university unions, rodeos, shooting galleries, boyscout associations, blue collar jobs, trade unions (Nylund, 2007). In this context men had calculable quasi-macho, modern men's parts, which in spite of being politically incorrect, especially from the point of view of women/wives forced into housekeeping, served as a basis for the important feeling of stability and calculability. The success of feminist and civil rights movements perfecting 
themselves following the sixties "corroded" and quickly eroded the foundations of the modern roles of males and masculinity connected to it: men found themselves in heterogeneous roles, which were not only unknown, but also new for them. The quick spread of the family model with two earning members, the engagements into the education of children narrowed down the old legitimate forms and the possibilities of expression of modern masculinity. Nonetheless, the multiculturalism, the movements and the positive discrimination of sexual minorities, as well as the normativity of politically correct common talk becoming dominant clearly excluded the reversion to any macho masculine model. So, at the turn of the millennium the two main forms of commercialised masculinity have developed, which constitute the frame for possible masculinity in the postmodern era.

The masculine types and roles called the "new man" and "new lad" (Nylund, 2007: 9-11) represent behaviour models and masculine traits adjusted to post-Fordist economy. "New man" denotes a conformist consumer man, who is pro-feminist, accepts women as equal partners, he is sensitive and emphatic (with "girlish" features, which he considers natural), he is a good and ambitious father and husband, expressing his opinion in a political correct way (regarding homosexuality, racial-ethnic minorities). Against this, the "new lad" is sporadically sexist, nostalgic and revisionist towards old (e.g. modern) masculinity, rather hedonist and looks for homogeneous masculine spaces; a kind of post-lad, the chav/YABBO or macho of global corporate capitalism. However, both of these masculine roles are self-reflexive, self-ironic, and filled with a feeling of uncertainty (Nylund, 2007: 12). Both of these roles are exposed to the movements of the labour market, to the dynamics of family and couple relationships. These two roles are completed by a more narcissistic third one, the metrosexual masculine role, which does not only approach the elements of earlier male and female roles but unifies them.

In Romania, modern masculine roles significantly changed during the de-industrialization, when the unemployment affected the working classes, which this way lost its earlier privileged position both in society and family. Under the circumstances of forced urbanization and industrialization, the majority of working men were characterised by macho-masculine roles, which expressed themselves in the public spaces of workplace, family and residence. Working class attitudes characterised everywhere by a culture of workers, and the ethos of work were dominant: there existed a prominent functional and value difference between the genders, and women's work was considered of lower value here, too. Prestige of women's work was negligible compared to men's work (which meant "hard physical work"). In workers' culture, besides the difficulty of men's work (it demands a lot of energy, firmness, resolution) there is also a strong 
sexual charge (Willis, 2000). In speaking, posture, movement, the showing off the objective features of physical strength (muscles, moving heavy objects) are the expressions of valuable masculinity. All of these are the means of making power conditions conscious, of continuously representing and expressing the relationships between men and women, men being the possessors of the power over women, including the disposition over them. But becoming unemployed created a new situation also in the relationships between genders, because many men were practically "forced into housekeeping", they had to do "housework": the work that they had undervalued earlier in comparison with their work in the factory. However, the majority of women held their jobs, because following de-industrialisation the demand for typical women's jobs like shop assistant, waitress, cashier and dressmaker remained stable on the labour market.

Women had to do their housework too, so this way they were charged by double burden, which became the source of series of conflicts. Ex-workmen insisted on the patriarchal model that had been socialised earlier, because it remained the only resource of their identity. In the eyes of men, the value of women's work, as well as the women's earning work types were low; in spite of the fact that these assured the outliving of the household (Pásztor, 2002). But by and large the masculine roles emerging after 1989 are similar to the two main types described by Nylund (2007), which are completed with the metrosexual type appearing mainly in the world of football and celebrities. ${ }^{6}$

Nylund, in his paradigmatic book Beer, Babes and Balls. Masculinity and Sport Talk Radio (2007) maintains that for unstable and changeable masculinities sports, or more precisely sports radios represent a "fix point", which dissolve the social pressure weighing upon post-modern men (pressure coming from the job and family), and help men collectively and discursively build up an acceptable and functioning masculine identity. He argues that sports radios create a third space besides workplace and family - most men are in need of, as because of the continually growing work time and expanding family tasks they need to deal with themselves as men, to construct, express and experience their male-self, while the two former spaces do not give them the possibility for this: in their workplace, they fulfil the role of an employee, and at home they find themselves in the role of a partner/companion. As an active member of the audience that calls into sports radios, the masculine role of post-modern men comes into the foreground, and thus this symbolic community becomes suitable to shape up "male romance"; where men can appear, take a position, play jokes, be self-ironic starting from the same status as the other men, without risking possible sanctions. This speech community ${ }^{7}$ fulfils an extremely important positive function: it creates a bond

\footnotetext{
${ }^{6}$ Adrian Mutu, as well as fashion designer Catalin Botezatu impersonate this form of masculinity.

7 In my case the reader community.
} 
with the other men, strengthens male traits, and provides an acceptable identity. In practice, all this is attained along the practice of discursive divergence: by the parody of female athletes, the underrating of sports branches considered unmanly, thus womanly, by the ridiculing of erring athletes. Along common topics ("the science of soccer"), words and expressions that can only be decoded by men, specific rules and norms of speech developed and applied during the debates. Moreover, specific procedures, linguistic forms and ways of expression, meanings, contemporary men are able to build and live a masculine identity that is needed to get along under the stressful circumstances of everyday life, on which they can rely. Sports radios do exactly that: they provide chance and opportunity for the callers and the male audience to dissolve the cumulated tension of everyday life along topics related to beer, girls, and the soccer ball, to mitigate the insecurities of post-modern masculinities, and offer an acceptable pattern of masculinity (2007: 155-165).

The model described by Nylund can well be applied also in Romania. Although with lesser audiences, there were two sport-talk radio stations functioning in Romania: GSP Radio and Sport Total Radio. Both talked about football and they had call ins. Both the hosts and the men calling in made sexist remarks, posing as football experts. ${ }^{8}$ In one word: although they talked about

${ }^{8}$ Just take a look at the 28 March 2013 programme of GSP Radio, broadcast between 14-15 hours, entitled pariori.ro. Dan Bara and Dan Chilom were the hosts. In the transmitted programme the chances of the teams playing on the Friday rounds are pondered, providing assistance to the audience interested in pools. That day the "face" of the radio station, Gabi Safta was invited; this is typically a talk show type broadcast, where the issues are debated together with the callers. The topic was the performance of the Romanian national team in Amsterdam, as it had been defeated two days earlier by 4-0 by Holland, in a qualifying match to the 2014 Brazil World Cup. The discussion was about the alleged revelry after the match of some of the representative players of the national team from Steaua, respectively the evaluation of coach Victor Pițurcă. Several supporters called in to repeatedly express their bitterness in connection with the serious defeat, and to criticise the coach and the light-minded players. The conversation started around the alleged "revelry" of the players, as there had been some rumours that five players only returned to their quarters at dawn. In the beginning, they only talked about their staying out, subsequently the conversation was diverted towards revelry and drinking, until finally (as one of the hosts expressed his view that clubs in Amsterdam all close at two in the morning, therefore the players must have spent their time in the Red-light district), by the time the first call came in, it was taken for granted that the players had spent their time drinking with prostitutes. The issues that were debated according to this were related to marital fidelity/infidelity, professional obligation, poor performance, incomes of soccer players comparing to the income of supporters and their rightful expectations and the tensions within these. Both the hosts and the callers condemned the players for spending time with prostitutes, a fact that was placed in sharp contradiction with their performance during the match, respectively with the lack of obligations towards their respective wives and girlfriends. In the view of the callers, the soccer players had betrayed the confidence of spectators and soccer fans, had played irresponsibly, thus failing to meet the rightful expectations of supporters. They were ridiculed and their market value was evaluated cynically. The high incomes of football players as opposed to the shrinking salaries of crisis stricken supporters only highlighted the unacceptable, 
soccer, most of the things they said were also about Romanian men and their social circumstances.

\section{Football, Nation and Hegemonic Masculinity}

Soccer does not only play a role in the crystallisation of individual masculine identities, and the momentary and virtual dissolution of internal tensions, but it can decisively contribute to the birth of modern nations, and the symbolic expression of national identity which is perceived as primordially masculine by Archetti (1999). According to the Argentinian anthropologist football and modernization, respectively nation building, are closely intertwined with the masculine features of typical males.

Football could gain such significance in the course of the specific evolution of social history of the Argentina. The country started its journey on the road of industrialization and modernization as a result of British influence, and by the end of the nineteenth and the beginning of the twentieth century it became popular in the eyes of Europeans; particularly Italian and Spanish immigrants. In less than forty years by the time of the outbreak of WWI six million immigrants arrived on the land of the pampas, resulting in an extremely heterogeneous population. The mix of the cultural characteristics of traditional (rural and agrarian) and modern (urban and industrial) traits, as well as those of the natives and the freshly large arriving immigrant groups resulted in a remarkably colourful cavalcade; Archetti used the term hybridization for this macro level social process (1999: XV), but he denotes the micro level manifestation of the phenomenon (the local, specific type of hybridisation) by the term of creolization, and sometimes the equivalent miscegenation (Archetti, 1999: 23-

\footnotetext{
immoral character of their "deeds". Talkers agreed that in the case of an occasional victory all this could have been forgiven perhaps, but a defeat of 4-0 cannot but underline the moral deficit of the players. Only men called in during the programme. Wives or girlfriends were only regarded as extensions of the soccer players themselves, prostitutes in Holland were obviously disparaged, and there was a consensus that they were nothing but sexual objects that corrupt the players. In connection with the alleged deeds of the players, the ambivalence was continuously present that something is allowed or forbidden depending primarily on the performance of the players. Generally speaking, a man with a good professional performance can rightfully commit an "offence" (drinking, adultery), while unsuccessful men better "sing small". All of the men calling in reflected upon their own (insecure) employment situations, which would never permit them to stand against their superiors in a case of bad performance at their works - comparing the relationship between players and their coach as a relationship between subordinates and their bosses. In what concerns language usage, speakers (especially the hosts) used notions with a double meaning, or with a sexual connotation, underlining the homosocial, masculine character of the programme - just like in the case of The Jim Rome Show analysed by Nylund (2007).
} 
45). It can be understood that under these quickly changing circumstances, the "invention", and the planned elaboration of modern Argentinian nation became urgently important for the local elites - just like in Eastern-Europe. The nation, as an imagined community, can be shaped along common features, which they thought they had found in football, tango, and polo (Archetti, 1999). The "unification" of high degree social heterogeneity into a political nation seemed to be feasible through football, and its accented masculine traits were transposed to typical Argentinianism. This is how the overall general discourse on specific football style and male footballers could become a dominant discourse on the nation, thus constituting a deep, moral bond among multiple identities based on ethnicity, origin, region and affiliation to social segments (Archetti, 1999: 226). So, football became an instrument for nation building, with the primary task being not only the construction of the nation and of national consciousness, but also implicitly the drawing of Argentinian masculinity, regarded as typical. All this meant the elaboration of a hybrid, the setup of a moral pattern that could be described by gendered features (gendered morality), in which the physical body of the Argentinian male, its aesthetic beauty, the manifestations of his behaviour and the common national morality were linked organically. All this was well mapped by football: mutually respected rules (fair play as morality), the players (their physical bodies, movement, as the representation of common social body) and the spectacle of the game (its aesthetic beauty) were symbolically able to shape this male hybrid, and present it repeatedly for the society. As a result, the criollo style of play became equal with national identity, naturally wearing masculine traits (Archetti, 1999: 46-54).

Stressing upon masculine features and characters they created a creole, Argentinian type of soccer as a peculiar local hybrid. The criollo style built on refined body movement, on spectacle, and on spectacular solutions meant to dazzle the audience. In this logic masculinity - as a creole hybrid - bears the marks of restless, individualistic, talented and agile individual features, in which elegance is of central importance. The cult of dribbling (Archetti, 1999:56-65) expresses the two main Argentinian masculine virtues: creativity and liberty. In contrast with the logic of the British playing style built on the mechanic, rational division of labour and the simple execution of tasks, the style of creole soccer is animated, creative, full of unexpected solutions, beautiful, spirited. The movement of the player is virtuosic, just like the performances full of surprises of violinists and pianists. To demonstrate the differences between the British and creole style (and between English and Argentinian men) one could say the soccer of the British (and their society) is built on instrumental rationality, whereas the playing style of the Argentinians (and their national community) on communicative rationality. In other words, while the style of the British reminds us of work, the 
creole playing style of Argentinian men evokes theatrical performances. All this has got a social historic determination. English men have learnt to play the game in school, under stern and rigid supervision, under the supervision of teachers and coaches, as part of the compulsory curriculum. Power and unequal social relationships are automatically encoded in this connection. Argentinian children the men of the future - discovered football on the grounds (potrero), outside school, uncompelled, and together with their mates, finding pleasure in it. Because of the narrowness of the ground and the large number of children, goals could only be scored after the successive dribbling of the others: for that it was important that players have the ability to keep the ball, and prevent others from taking it away. This became a national masculine quality that defined Argentinian men: they had to rely on their inventiveness, ability to manoeuvre in order to succeed in life. In this criollo style the beauty of the game overwrote success; and this is the essence of local masculine philosophy, the central nucleus of potrero-ideology (Archetti, 1999: 173).

The archetypical character of Argentinian males and football is the pibe (Archetti, 1999: 181), the permanently free man, the "true son of the people" (pibe del oro). The pibe evokes the image of a child (a child, not a son), who achieves social appreciation using his own resources, who is perfect as a player, can rise from tight corners, is resolute, but also elegant and creative - but deep inside continues to be a child, honest and most importantly: free... Maradona stands closest to this hegemonic character.

Based on the model developed by Hadas (2003) I will take a look at how football and the modern Romanian man is constructed by the domestic sport media where the presented contradictions and moral differences between local and foreign coaches resembles to Archetti's interpretation.

\section{Football and Romanian Masculinity}

Based on the attributes used in the football discourses I can sketch the image of current Romanian men. The general attribute is "Latin". The following are of great importance: character, perseverance, determination and discipline. Manly players are characterised by self-confidence, are creative and able to manoeuvre well among quickly changing circumstances and opponents. Besides creativity, trickery represents further value. The true Romanian (football) men are able to set things right around themselves, and conveys authority, prestige towards their environment: the most often used term in the discourse about football is order; tactics and knowledge only comes after that. In soccer slang there is an attribute that cannot be translated easily, and that is "tupeu" - some sort of 
cheekiness, denoting a self-importance respected and accepted by the others, but which is also coupled with outstanding talent. This also means that the respective person is a boss on the field.

These particular values resemble the characteristics of Argentinian men in many respects; probably due to the comparable power-related and historical factors. If there is a difference that is mostly connected to the fact that in our case we are talking about the Austrian political-historic influence rather than the British, and the reference is Viennese/Danubian or Bucharest football and foreign coaches. But let's have a look how the hegemonic masculinity is constructed in football discourses in which the local coaches play a central role.

The media narrative on masculinity is a coherent story, and the chosen individual cases are well-composed pieces of a meta-history. The "small stories" rendered to the coaches are not biographical stories but "here and now" snapshots about their works and solutions. The drawn biography of Romanian coaching is built of these momentums - which, alongside the common characteristics point beyond the particular cases. The narration is built on the stories of two different types of coaches. There are the "great names", such as Mircea Lucescu, the "greatest Romanian coach presently", László Bölöni, the "the great ex-player and a successful coach" or Cosmin Olariu "of the young generation." There are the "talented" Dan Petrescu, or Dorinel Munteanu, "the coach presently working abroad". They are characterised by coaching abroad - they are talented without doubt, have reached outstanding results, but cannot work in the Romanian conditions either because "they are too elegant and sophisticated" (Bölöni), or "too expensive and independent" (Lucescu, Petrescu) or they had "unpleasant experiences" earlier (Olăroiu). Under the present conditions - although Romania would really need them - they are not in the country. In the narration they are a kind of luxury "strawberry pickers" leaving their country to be successful abroad. Dorinel Munteanu - nicknamed by the funs as the "German" for his seriousness, hard work on and off the pitch and for his successful career in Germany - is also mentioned as a "healthy" form of Romanian masculinity, in opposition with "toxic" masculinity represented by the club owners (embodied by FC Steaua stakeholder George "Gigi" Becali), but he never became the central figure in the media narratives. Interestingly, active and well-known players like Marius Nicolae or Raul Rusescu are totally missing from the soccer discourses regarding the masculinity. So, the essence of Romanian masculinity is built around local coaches.

The other group is composed of those working at home, but under problematic working circumstances; they were either dismissed, (e.g. I. Andone), or they are successful, in spite of a bad coach-club owner relationship (L. Reghecampf), or they work unknown, far from the attention of the audience, at smaller regional teams (P. Grigoraș; C. Pustai; I. O. Sabău). They are the ones still working at home or "have not yet left the country". 
The successful coaches of the third group (like Jenei I.; Kovács I.; V. Stănescu) direct the attention to the glorious past. The narrative creates by them stresses the continuity within the community of coaches, the organic relationship between football past and present, the direct lineage of hegemonic masculinity.

Yes, we speak after several years with the gentle and good-tempered Emeric Jenei, the coach of the great victory in Sevilla. True, he was then younger with a quarter of a century. That is what Uncle Imi told his pupils in the times when Anderlecht or Honvéd fell like heads of corn in Ghencea. Equally true that the great coach also had listeners to address. (ProSport, 16.02.2012)

The human qualities - determination, steadiness, honesty, pride, mutual respect, knowledge, tenaciousness, sense of vocation, solidarity, spirit of fighting - on the basis of which they performed their successes in spite of the surrounding external impediments, are valid for each of the coaches mentioned above as models. In this approach, inner qualities constitute the token of success, inner qualities, which, according to the narration, are rather scarce especially amongst the club owners, but also within society. The values in question construct the normative model of Romanian masculinity. Because there is another similarity among the mentioned coaches: all of them are Romanians, or if they belong to an ethnic minority (like Jenei, Bölöni, Kovács), they are accepted as Romanians. Rarely appear foreign coaches in this pantheon (C. Bergodi, but the end of his Romanian career was attributed to his excessive stylishness and decency).

Bergodi scored a moral victory as all of the past and future conquests of technical players going through Ghencea. Steaua has to thank the Italian that he had given them an example of professionalism and manhood. Because he behaved like a coach and not like a slave. Without making a fuss of it. In fact there is nothing heroic in his gesture. This is normality. (GSP, 18.09.2009)

So these masculine qualities belong to the Romanian coaches, and by the application of linguistic transitivity they also indirectly mean Romanian masculinity.

Why do they believe in Dorinel? He is totally devoted to his work (...). He knows exactly what he wants (...). He creates the atmosphere. Although the man of record caps at the national team, Dorinel does not take pride in this, neither outside, nor inside the locker room. He gains respect from his competence. The player respects him because he gets uprightness in evaluation, knowledge in the preparation for matches, diversity in trainings in exchange. He does not consider the possessor of absolute truth, he is a good receiver of the useful ideas of the team. All these create that binding atmosphere, the background in which the results appear. (GSP, 28.10.2008) 
Among central symbols I found expressions like trophies, performance, and masculinity. The applied discursive strategy presents outstanding coach performance and masculine behaviour, it blows up the significance of successes and puts them in sharp contrast with the Romanian conditions of football, considered limitative. The presented identity of the coach is equated with the status of the employee, to which the perspective of the narrator also corresponds: the story of coaches in the narrative is built up from this point of view, and gets completed with the identity of the average employed Romanian man. Its function is to show up the coaches' real working situation, and to draw the traits of Romanian men, in order to provide an answer to the nature of general masculine identity.

The narrators apply the instruments of description and transitivity, while football serves the aim to give a basis to discursively build up individual identity and masculinity. For the coaches, the ball game constitutes the medium through which they can express their identity and can implement the qualities characteristic to the real Romanian man. The narration approaches positively the coaches - in contrast with the club owners and sports leaders - they are the main characters of this story. The topic of masculinity is more complex to be related solely alongside talkative positive examples. It also relates about what does not constitute the model of Romanian masculinity. In parallel with this, I present in the following additional material about further circles responsible for the present state of affairs of the "soccer situation" - its lack of success, corruption, conflicts between the characters.

This narrative on masculinity lacks ambivalence: it denotes fake, pseudo-masculine manifestations in negative terms. The majority of the subjects about whom the narrative contrasts - are trainers from abroad ${ }^{9}$ or celebrity players, but several club owners consciously looking for the attention of the media also belong to this circle. ${ }^{10}$ The discourse functions by a simple strategy. It solely constructs negative cases, which can obviously be condemned. It strongly blows up the subjects' weaknesses, but hides and conceals positive exceptions - for instance successful foreign trainers ${ }^{11}$ and the performances of foreign players. Here the presented characters wear strong labels, to which negative meanings are rendered. The texts make each label unambiguous, not making possible any positive connotations. Not only the names, but also even the scenes where they appear get negative values. Such scenes are TV studios late in the evening, night clubs and places of entertainment, but even unsuitably prepared training fields.

This has got two iconic symbols: Italian trainer Dario Bonetti and Dinamo's ex-player Adrian Cristea, the celebrity player of the team U Cluj during my

\footnotetext{
9 Primarily José Peseiro, Luis Caro and Dario Bonetti.

10 Primarily Cristi Borcea from Dinamo.

11 Cristiano Bergodi or Dusan Uhrin jr.
} 
research. In discourses Bonetti obtained the label of the Buffoon (Bufonul), while Cristea the "rank" of The Prince.

(...) The Prince played against CFR with a plus of an ambition and even a plus of a speed, but the general impression is that he still remained indebted. Inasmuch according to a larger opinion, he enters the narrow category of the football players who - benefitting of the many talents they had received from nature - should be able to win a match all by themselves. Not always, perhaps, but at least every now and then. As he failed to do so again on Saturday, it became clear that it takes little for Adi Cristea to be satisfied, he proves to be a man of pleasure. Because of this the whole community suffers, but mostly Adi Cristea himself does. (GSP, 21.11.2011)

The case of Bonetti is simple: a former Italian player who had made it into the national team, and then, at the beginning of his career as a coach, signed a contract in Romania, in June 2009, with Dinamo Bucharest. The goal set by the club is to win the national championship and make it for the Champions League in the next season. Bonetti's activity comes to a sudden end in October, when he is fired. Parting is scandalous; the parties each cast the blame on the other side in their declaration on TV (the club frequently mentioning the performance that failed to come, while the coach the promises unfulfilled and the benefits not received). In the April of 2012, he suddenly "returned" to the team with a mission to save the season, when the team was the seventh on the league table. His career proved to be a short once again; he was dismissed once more in November, while the team continued to be the seventh on the league table.

The tow unsuccessful attempts, and the many declarations in which he posed in the role of the saviour, made him an ideal scapegoat. His arrogance disturbed the authors. "I am only arrogant with the ignorants", he declared.

In spite of his intentions, Bonetti has become one of the main symbols of foreignness in this narrative. ${ }^{12}$

I was ignorant: I have never heard of Bonetti until his first term at Dinamo. (...) I claim my right to be ignorant: as I say that Bonetti used to be a great player, I also have to affirm that as a coach he is only one in a dozen. Just like Dinamo has become under his guidance. (...) I ignore my unjust arrogance: immediately after League 1 had escaped "una grande partita", I heard one of the commentators trying to elegantly save the appearances: "Good thing that he left!". (...) And the bottom-line is: before leaving for the Caribbeans, Bonetti would have liked to take another tour in the old downtown, together with his lads from the Nuova Guardia. (ProSport, 16.11.2012)

12 The other one was the captain of CFR Cluj, Ricardo Cadú. 
His false masculine manners were the subject of critical remarks and parody, xenophobia and racism, but also sexism rose to the surface in connection with his personality. All this in connection with the fact that the number of foreign players playing in the Romanian championship had increased continuously since 2001, with an increasingly sharp competition between autochthonous and foreign players on the transfer market, in favour of the latter. It is not uninteresting either, that the performance of the national squad started to deteriorate, while the proportion of foreign players continuously and steadily increased, and after 2000 Romania failed to qualify to any international competition. The two processes do not necessarily correlate, but the general public and the commentators began to talk about them more and more frequently as interconnected phenomena.

Adrian Cristea ran another course. The Dinamo player Cristea had been the player of the Iasi team (2001-2004), he played here until 2010. Thus Bonetti was his coach for a while. In the beginning the nickname of Prince was used by the media in a positive sense, to denote a talented hope. It had been attributed earlier, in the late sixties and early/mid-seventies of the last century to a legendary football player, Nicolae Dobrin (wearing an aristocratic nickname like the Prince even meant risk). Thus the Prince evoked a "new Dobrin" in Cristea, but the meaning of the word increasingly slid towards mundane behaviour, the role of a mediatise heartbreaker celebrity and less and less referred to the status of a football player, or to his (wasted) talent. The term of "Prince" gradually became a label/stigma, while the narrative discovered in him the symbolic representative of all irresponsible players, a false masculinity. A significant part in that played his boisterous and overly mediatised relationship with a celebrity miss, Bianca Dragușanu.

I find Adrian Cristea sympathetic. He is some kind of a James Dean lost in time and space, with a glance hovering above waters, as if he was always laughing at everybody and particularly of himself. Always living at another speed than the others - in Dean's case it had been the fury of adrenalin, at Cristea it is the mania of challenging silence, of shrewd deceit. Anything, just to be different from the rest. (...) He's heading for a crash. (...) Cristea is the poster of a generation left to fly without wings and which constructs from "Fronde" the vocation of falling. Some sort of twisted Spartans, a sacrifice of wasting. (GSP, 01.12.2009.)

So, the unprofessional, pseudo-masculine coach and false player identity appears, presented by the speakers from the symbolic position of a true Romanian male (coach). Its aim is to defend the market interests of Romanian coaches and to deconstruct the pseudo-masculine patterns of the "foreigners": to strengthen the autochthonous Romanian model of masculinity, to point out the well identifiable circle of those responsible, too. Those, who can be made 
responsible for the weak performance of Romanian football, and the loss of ground on the labour market of domestic coaches and players. All these in spite of the fact that the number of foreign coaches is low in the Romanian championship. The total number of fifteen coaches ${ }^{13}$ appeared in the period of my analysis. Among the applied means, generalisation, and description, respectively stereotyping can be observed, while the story against the subjects is clearly condemning, strongly satirical. Among the central notions of the narrative I found Dinamo, Bonetti, Cristea, impertinence. Yet football only creates the basis for the deligitimization and deconstruction of pseudo-masculinity, and the strengthening of true Romanian masculinity.

But then what does not count as masculine? The way of speech articulated along coordinates like Romanian coach-foreign coach, and professionalunprofessional identified pseudo-masculinity along external marks, to which it explicitly placed itself in opposition. Bonetti was clearly unsuccessful; he was Italian and he frequently made self-confident declarations. This constituted the "realistic" basis of the constructed image of Bonetti. He failed to save Dinamo; thus he cannot be a professional either. If he is not a professional - only presents himself as such - then he cannot be masculine either (as we have seen, professionalism and masculinity are closely connected). The picture drawn is not at all flattering. He behaved spectacularly in his outward appearance, dressed unconventionally (Italian style), could hardly speak Romanian (foreigner), talked in an off-hand manner with old players (arrogant), and preferred foreigners (looked down on Romanians): the image of an ideal scapegoat. Thus pseudo-masculinity can be caught in the constructed image in its external habitual features, whereas real implicitly Romanian-masculinity - means internal qualities. Cristea-type mundane, celebrity, outward behaviour does not count as real masculinity.

The fact that Bonetti is an Italian cannot be neglected. Romanian football sees Italian football as a model it tries to "copy". A part of the coaches are great admirers of the tactics of the Italians, and the press calls many of the "clones" of Italian coaches - for instance often speaks about Mihai Stoichiță as "the Lippi of Romania". The victory over Italy in 1983 counts as one of the peaks of Romanian football history. At the same time, Italy has been one of the most popular targets of Romanian foreign workers since 2007. The incidents widely publicised in the Italian press about the unlawful acts of Romanian immigrants, come down hard on Romanian public opinion and they also have soccer connections. ${ }^{14}$

\footnotetext{
13 Maurizio Trombetta; Ales Jindra; Dusan Uhrin Jr.; Toni Conceicao; Toni Conceicao; Andrea Mandorlini; Jorge Costa; Paulo Sérgio; Dario Bonetti; Jose Peseiro; Massimo Pedrazzini; Cristiano Bergodi; Ronny Levy; Augusto Inácio; Lopez Caro.

${ }^{14}$ In the fall of 2008 Nicolae Mailat was accused of murdering a wife of an Italian admiral. The news generated anti-Romanian manifestations. After the event, in the Olimpico Stadium in Rome, the spectators shouted racist insult and booed at Mutu, calling him a "Gypsy".
} 
The "botcher" coach in this context is an excellent opportunity to turn the Italian-Romanian relations "upside down", and to equalise an unequal situation. This is what the narrative does in fact, while it also defends the interests of domestic coaches and players. The criticism of professionalism and unworkmanlike behaviour appears in a xenophobic tone that is legitimised by the narrative: it instils that they are too many. Foreign players appeared in the Romanian championship after 2000. Earlier the migration of Romanian players to foreign teams was more characteristic. As the population of the country became more and more engaged on the international labour force market, the number of those undertaking work in Romania also started to increase. The majority of these were company leaders and soccer players.

Their proportion increased steadily. In the 2001/2002 season their proportion in the starting teams ${ }^{15}$ was only 1 percent, which was negligible. This did not really change until the 2006/2007 season, when the presence of one foreign player becomes regular in starting teams. Two seasons later we already find three foreigners on average in a team on the pitch, and in the $2011 / 2012$ four. Their distribution is obviously very unequal: in the case of stronger teams the majority of the selection is made up of foreigners; among these the CFR in Cluj had a pioneer role. In the 2012/1013 season, more than two thirds of all the players of the CFR were foreigners, whereas there were only five of twenty-nine in the team of the main rival Steaua. No surprise that xenophobia became closely linked with CFR, which appeared as "foreign team" as compared with "autochthonous" Steaua.

The fact is that in the narrative mostly calibrated in Bonetti, the question of foreignness is in the foreground. It is also expressive that the term of foreigner is frequently used instead of foreign legionnaires. The term legionnaires and the Italian sounding stranier is reserved to designate Romanian football players playing abroad. The way of speech does not only find the number of foreigners too high, but often presents value judgments: "only the scrap comes", "they could not be successful elsewhere", "they are worthless". Players coming from Africa for instance are often only referred to as "blacks" that have got "civilisation problems". In this respect, it is very expressive how CFR player Lacina Traoré was presented in the press. About the player from Ivory Coast, who came to Cluj as a teenager in 2008, they considered important to remark that he had never seen shampoo before and had never taken a shower. In the case of the player, who has since played for AS Monaco and presently playing for the English Everton, it is expressive that words like black or African work as a marker, and over-emphasising his exotic features is racist.

15 The proportion is calculated for all the teams, a number of 18 in total. 
The connection between unworkmanlike - unmasculine behaviour - and racial origin is even more explicit in the case of Osumane N'Doye, a player who had played for several other teams before. The Senegalese forward, an offspring of rich parents, is often in the limelight because of his happy-go-lucky way of life. “N'Doye is not a bad boy, N'Doye is just unprofessional. A professional player means in the first place rules. Rules, rules, rules." (GSP, 21.11.2010)

The connection between the black and/or African marker and the "fancy nightclub" underlines foreignness and the lack of masculinity. The picture is further shaded by the fact that the narrative explicitly shows an ideal-type of hegemonic masculinity: the Serbian Novak Martinovic, who demonstrated the male model to follow on the "field of actions". Martinovic became a "celebrated warrior" during a match between Petrolul Ploiești and Steaua Bucharest. ${ }^{16}$ In $45^{\text {th }}$ minute of the half-time, a local supporter ran onto the pitch, and hit George Galamaz with an iron rod on the back of his head. The aggressor continued to run with further intentions to attack, but Martinovic kicked and thwarted him with a quick and accurate movement, while his companions only watched paralysed. By his deed Martinovic became an instant hero: the articles praised him with words like "a true man", with "determination", "self control", "powerful", "combating". The posing of the issue draws a central characteristic of masculinity. Thus he became a Romanian, a "Real Man", embodiment of domestic hegemonic masculinity completing the features of local coaches.

\section{REFERENCES}

Anderson, E. (2008). I Used to Think Women Were Week: Orthodox Masculinity, Gender Segregation, and Sport. Sociological Forum, 23(2): 257-280.

Archetti, E.P. (1999). Masculinities. Football, Polo and the Tango in Argentina. OxfordNew York: Berg.

Connell, RW; Messerchmidt, J.W. (2005). Hegemonic Masculinity Rethinking the Concept. Gender and Society, 19(6): 829-859.

Connell, RW (1983). Which Way is Up? Essays on Sex. Class, and Culture. Sidney: George Allen \& Unwin.

Connell, RW (1990). An Iron Man: The Body and some Contradictions of Hegemonic Masculinity. In Messner, M., A-Sabo, D.F. (Eds.) Sport, Men and the Gender Order:

Critical Feminist Perspectives. Champaign, IL: Human Kinetics, p. 83-95.

Connell, RW (1995). Masculinities. Cambridge: Polity Press.

16 Ilie Ioana Stadium, Pitesti, 30 October 2011. 
Connell, RW (2002). Gender. Cambridge: Polity Press.

Hadas, M. (2003). A modern férfi születése. Budapest: Helikon.

Kimmel, M. (1996). Manhood in America: A Cultural History. New York: Free Press.

Messner, M. (2004). "Still a Man's World? Studying Masculinities and Sport.” In Kimmel, M.S.-Hearn, J.-Connell, R.W. (Eds.) Handbook of Studies of Man \& Masculinities. SAGE Publications, p. 313-325.

Nylund, D. (2007). Beer, Babes and Balls. Masculinity and Sports Talk Radio. Albany: State University of New York Press.

Pásztor, Gy. (2002). „Követem őt? A nemi szerepek változása a kommunista és posztkommunista időszakban." In Veres, V.-Gyarmati Zs. (Eds.) RODOSZ Tanulmányok III. Kolozsvár: Kriterion, p. 47-51.

Péter, L. (2014). Soccer and Society in Romania. Issues and Problems in Soccer Discourses, Jyväskylä: University of Jyväskylä.

Trujillo, N. (1991). Hegemonic Masculinity on the Mound: Media Representation of Nolan Ryan and American Sport Culture. Critical Studies in Mass Communication, 8(9): 290-308.

Willis, P. (2000). A skacok. Iskolai ellenkultúra, munkáskultúra. Budapest: Új Mandátum Könyvkiadó. 